Supplement of Atmos. Chem. Phys., 18, 1611-1628, 2018

https://doi.org/10.5194/acp-18-1611-2018-supplement

(C) Author(s) 2018. This work is distributed under

the Creative Commons Attribution 3.0 License.

(c) (1)

Supplement of

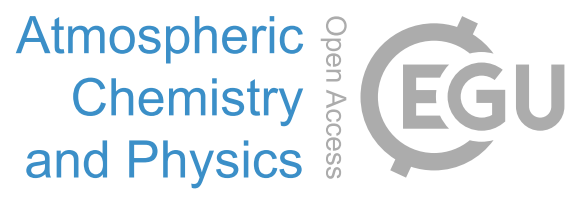

\title{
Effects of $\mathrm{NO}_{x}$ and $\mathrm{SO}_{2}$ on the secondary organic aerosol formation from photooxidation of $\alpha$-pinene and limonene
}

\section{Defeng Zhao et al.}

Correspondence to: Thomas F. Mentel (t.mentel@fz-juelich.de)

The copyright of individual parts of the supplement might differ from the CC BY 3.0 License. 
Table S1. Detailed conditions of the experiments in this study

\begin{tabular}{|c|c|c|c|c|c|c|}
\hline $\begin{array}{c}\text { Experiment } \\
\text { No. }\end{array}$ & $\begin{array}{l}\text { VOC } \\
\text { (ppb) }\end{array}$ & $\begin{array}{c}\mathrm{SO}_{2} \\
\text { added } \\
(\mathrm{ppb})\end{array}$ & $\begin{array}{l}\text { NO added } \\
\quad(p p b)\end{array}$ & $\mathbf{T}(\mathbf{K})^{\mathrm{a}}$ & $\begin{array}{c}\text { RH } \\
(\%)^{b}\end{array}$ & Scheme \\
\hline$\# 1$ & $\begin{array}{c}\alpha \text {-pinene } \\
(20.2)\end{array}$ & 0 & 0 & $304-311-314$ & 32 & $\begin{array}{l}\text { Low } \mathrm{NO}_{x} \\
\text { low } \mathrm{SO}_{2}\end{array}$ \\
\hline$\# 2$ & $\begin{array}{c}\alpha \text {-pinene } \\
(21.4)\end{array}$ & 0 & 19 & $307-314-317$ & 29 & $\begin{array}{l}\text { Low } \mathrm{NO}_{\mathrm{x}} \\
\text { high } \mathrm{SO}_{2}\end{array}$ \\
\hline$\# 3$ & $\begin{array}{c}\alpha \text {-pinene } \\
(17.5)\end{array}$ & 15 & 0 & 291-298-302 & 34 & $\begin{array}{c}\text { High } \mathrm{NO}_{\mathrm{x}} \\
\text { low } \mathrm{SO}_{2}\end{array}$ \\
\hline$\# 4$ & $\begin{array}{c}\alpha \text {-pinene } \\
\text { (18.7) }\end{array}$ & 15 & 17 & $300-303-305$ & 42 & $\begin{array}{l}\text { High } \mathrm{NO}_{\mathrm{x}} \\
\text { how } \mathrm{SO}_{2}\end{array}$ \\
\hline$\# 5$ & $\begin{array}{l}\text { Limonene } \\
\text { (7.4) }\end{array}$ & 0 & 0 & 294-303-307 & 31 & $\begin{array}{l}\text { Low } \mathrm{NO}_{\mathrm{x}} \\
\text { low } \mathrm{SO}_{2}\end{array}$ \\
\hline$\# 6$ & $\begin{array}{l}\text { Limonene } \\
(7.5)\end{array}$ & 0 & 25 & $303-310-313$ & 28 & $\begin{array}{l}\text { Low } \mathrm{NO}_{\mathrm{x}} \\
\text { high } \mathrm{SO}_{2}\end{array}$ \\
\hline$\# 7$ & $\begin{array}{l}\text { Limonene } \\
(7.8)\end{array}$ & 15 & 0 & 293-301-305 & 29 & $\begin{array}{c}\text { High } \mathrm{NO}_{\mathrm{x}} \\
\text { low } \mathrm{SO}_{2}\end{array}$ \\
\hline$\# 8$ & $\begin{array}{l}\text { Limonene } \\
(7.4)\end{array}$ & 15 & 17 & 296-305-309 & 28 & $\begin{array}{l}\text { High } \mathrm{NO}_{\mathrm{x}} \\
\text { high } \mathrm{SO}_{2}\end{array}$ \\
\hline$\# 9$ & $\begin{array}{c}\text { Limonene } \\
(6.0)\end{array}$ & 2 & 17 & $296-306-310$ & 28 & $\begin{array}{l}\text { High } \mathrm{NO}_{\mathrm{x}} \\
\text { moderate } \mathrm{SO}\end{array}$ \\
\hline
\end{tabular}

a: The minimum, average and maximum temperature are shown.

${ }^{b}$ : The average RHs of the period of monoterpenes photooxidation are shown. 
Table S2. Summary of the effect of $\mathrm{NO}_{\mathrm{x}}$ on monoterpene SOA yield in the literature

\begin{tabular}{|c|c|c|c|c|c|c|}
\hline VOC & Oxidation & $\mathrm{NO}_{\mathrm{x}}(\mathbf{p p b})$ & Seed aerosol & $\begin{array}{l}\text { OH source/OH centration } \\
\left(\text { molecules } \mathrm{cm}^{-3}\right)\end{array}$ & $\begin{array}{l}\text { RH } \\
(\%)\end{array}$ & Literature \\
\hline $\begin{array}{c}\alpha \text {-pinene } \\
15-30 \mathrm{ppb} \\
150-200 \mathrm{ppb}^{\mathrm{a}}\end{array}$ & Ozonolysis & $\begin{array}{c}4.6-2000 \mathrm{ppb} \\
{[\mathrm{VOC}]_{0} /[\mathrm{NOx}]_{0}} \\
0.65-391\end{array}$ & No seed ${ }^{b}$ & Low $\mathrm{OH}^{\mathrm{c}}$ & Dry $^{d}$ & $\begin{array}{l}\text { (Presto et al., } \\
\text { 2005) }\end{array}$ \\
\hline $\begin{array}{l}\alpha \text {-pinene } \\
15 \mathrm{ppb}\end{array}$ & Photooxidation & $\leq 2-1000 \mathrm{ppb}$ & $\begin{array}{l}\left(\mathrm{NH}_{4}\right)_{2} \mathrm{SO}_{4} \text { as } \\
\text { seed }\end{array}$ & $\begin{array}{l}\text { Low } \mathrm{NO}_{\mathrm{x}}: 3 \times 10^{6} ; \text { high } \mathrm{NO}_{\mathrm{x}} \text { : initial } \\
\qquad 2 \times 10^{7}\end{array}$ & $3.7-6.4$ & (Ng et al., 2007) \\
\hline $\begin{array}{l}\alpha \text {-pinene } \\
19.8-52.4 \mathrm{ppb}\end{array}$ & Photooxidation & $\begin{array}{l}\text { Low } \mathrm{NO}_{\mathrm{x}}: \text { not } \\
\text { reported. } \\
\text { High } \mathrm{NO}_{\mathrm{x}}: 800 \\
\mathrm{ppb}\end{array}$ & $\begin{array}{c}\text { No seed, } \\
\left(\mathrm{NH}_{4}\right)_{2} \mathrm{SO}_{4} \text { or } \\
\left(\mathrm{NH}_{4}\right)_{2} \mathrm{SO}_{4} \\
+\mathrm{H}_{2} \mathrm{SO}_{4}\end{array}$ & $\begin{array}{c}\text { Low } \mathrm{NO}_{\mathrm{x}}: \mathrm{H}_{2} \mathrm{O}_{2} / \text { initial OH } 2 \times 10^{6} \\
\text { high } \mathrm{NO}_{\mathrm{x}} \text { : HONO and } \\
\mathrm{CH}_{3} \mathrm{NO}_{2} / \text { initial OH } 6-20 \times 10^{6}\end{array}$ & $<10$ & $\begin{array}{l}\text { (Eddingsaas et } \\
\text { al., 2012) }\end{array}$ \\
\hline $\begin{array}{l}\alpha \text {-pinene } \\
12 \mathrm{ppb}\end{array}$ & Photooxidation & $\begin{array}{l}0.5 \mathrm{ppb}-60 \mathrm{ppb} \\
\text { (steady state) }\end{array}$ & $\begin{array}{l}\text { No seed, } \\
\left(\mathrm{NH}_{4}\right)_{2} \mathrm{SO}_{4}\end{array}$ & $\mathrm{O}_{3}(78 \mathrm{ppb}) / \sim 4-7 \times 10^{7}$ & 63 & $\begin{array}{l}\text { (Sarrafzadeh et } \\
\text { al., 2016) }\end{array}$ \\
\hline $\begin{array}{l}\alpha \text {-pinene } \\
13.6-20.4 \mathrm{ppb}\end{array}$ & Photooxidation & $\begin{array}{c}\text { Low } \mathrm{NO}_{\mathrm{x}}:<0.3 \\
\mathrm{ppb} \\
\text { High } \mathrm{NO}_{\mathrm{x}}: 66-82 \\
\mathrm{ppb}\end{array}$ & $\begin{array}{c}\left(\mathrm{NH}_{4}\right)_{2} \mathrm{SO}_{4} \text { or } \\
\left(\mathrm{NH}_{4}\right)_{2} \mathrm{SO}_{4} \\
+\mathrm{H}_{2} \mathrm{SO}_{4}\end{array}$ & 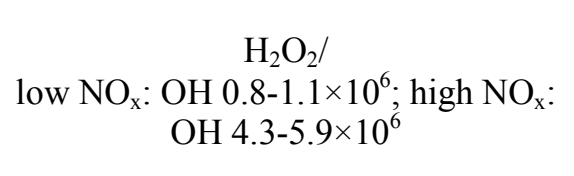 & $29-68$ & (Han et al., 2016) \\
\hline $\begin{array}{l}\alpha \text {-pinene } \\
16.1-31.7 \mathrm{ppb}\end{array}$ & Photooxidation & $\begin{array}{c}\text { Low } \mathrm{NO}_{\mathrm{x}}:<1.9 \\
\text { ppb } \\
\text { High } \mathrm{NO}_{\mathrm{x}}: \\
19.675 .1 \mathrm{ppb}\end{array}$ & $\begin{array}{c}\left(\mathrm{NH}_{4}\right)_{2} \mathrm{SO}_{4} \\
+\mathrm{H}_{2} \mathrm{SO}_{4} \text { or } \\
\mathrm{H}_{2} \mathrm{SO}_{4}+\mathrm{NH}_{4} \mathrm{HSO}_{4}\end{array}$ & HONO/N.A. & $23-75$ & $\begin{array}{l}\text { (Stirnweis et al., } \\
\text { 2017) }\end{array}$ \\
\hline $\begin{array}{l}\text { a-pinene } \\
\sim 20 \mathrm{ppb}\end{array}$ & Photooxidation & $\begin{array}{c}\text { Low } \mathrm{NO}_{\mathrm{x}} \text { : } \\
\sim 0.05-0.2 \mathrm{ppb} \\
\text { High } \mathrm{NO}_{\mathrm{x}}: 20 \\
\mathrm{ppb}\end{array}$ & $\begin{array}{l}\text { No seed or } \mathrm{SO}_{2} \\
\text { was added. }\end{array}$ & $\begin{array}{c}\text { HONO/ } \\
\text { OH: }(1-15) \times 10^{6}\end{array}$ & $28-42$ & This study \\
\hline $\begin{array}{l}\text { : Two levels of } \alpha \\
\text { : In one high NO } \\
\text { : OH scavenger } \\
\text { : RH was not spe } \\
: \text { OH concentrati }\end{array}$ & $\begin{array}{l}\text { lene concentrat } \\
\text { xperiment (NH } \\
\text { added. } \\
\text { ed. }\end{array}$ & $\begin{array}{l}\text { were used. } \\
\mathrm{SO}_{4} \text { was used as }\end{array}$ & ed aerosol. & & & \\
\hline
\end{tabular}




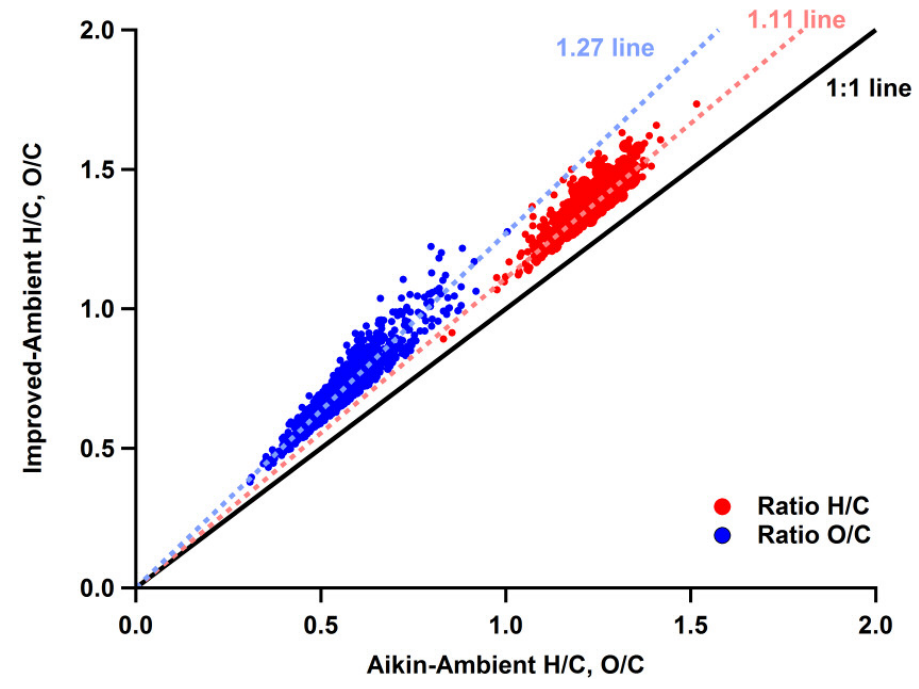

Figure S1. Comparison of the $\mathrm{H} / \mathrm{C}$ and $\mathrm{O} / \mathrm{C}$ obtained using the method of Canagaratna et al. (2015) with that obtained using the method of Aiken et al. (2007). 


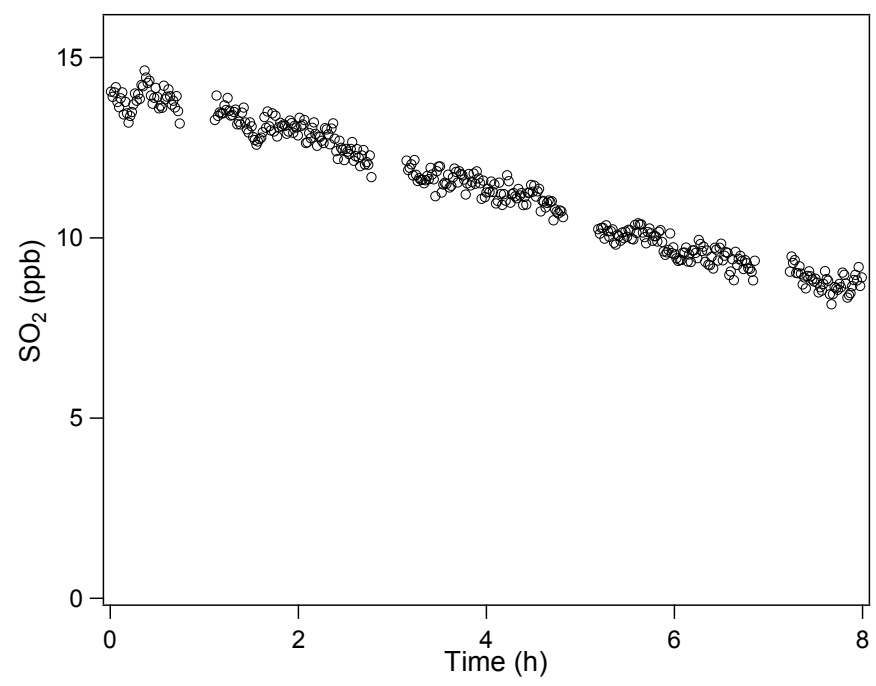

2 Figure $\mathrm{S} 2$. Time series of $\mathrm{SO}_{2}$ concentration in an experiment with $\mathrm{SO}_{2}$ added. 


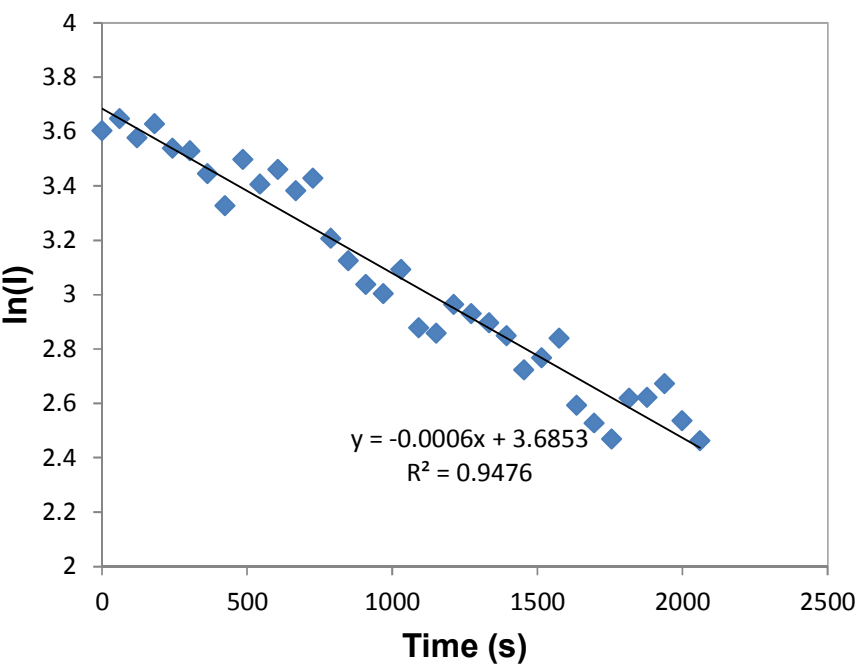

6

7 Figure $\mathrm{S} 3$. Decay of $\mathrm{C}_{10} \mathrm{H}_{15} \mathrm{NO}_{8}(\mathrm{MW} 277 \mathrm{~g} / \mathrm{mol}$ ) in the dark chamber. Y-axis shows the natural logarithm of the 8 peak intensity obtained from CIMS. The raw data were averaged to $1 \mathrm{~min}$. 


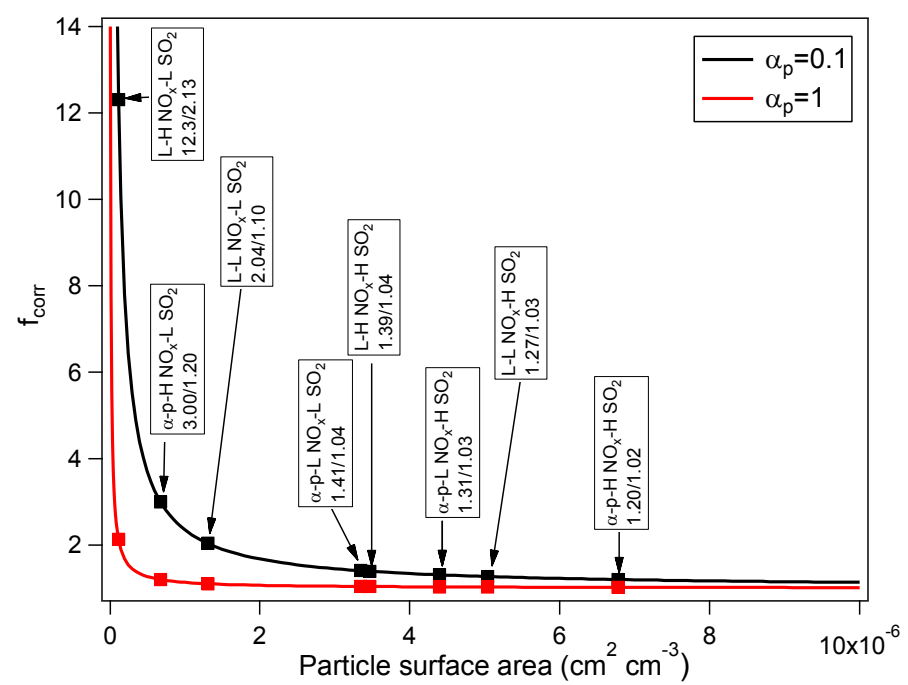

(a)

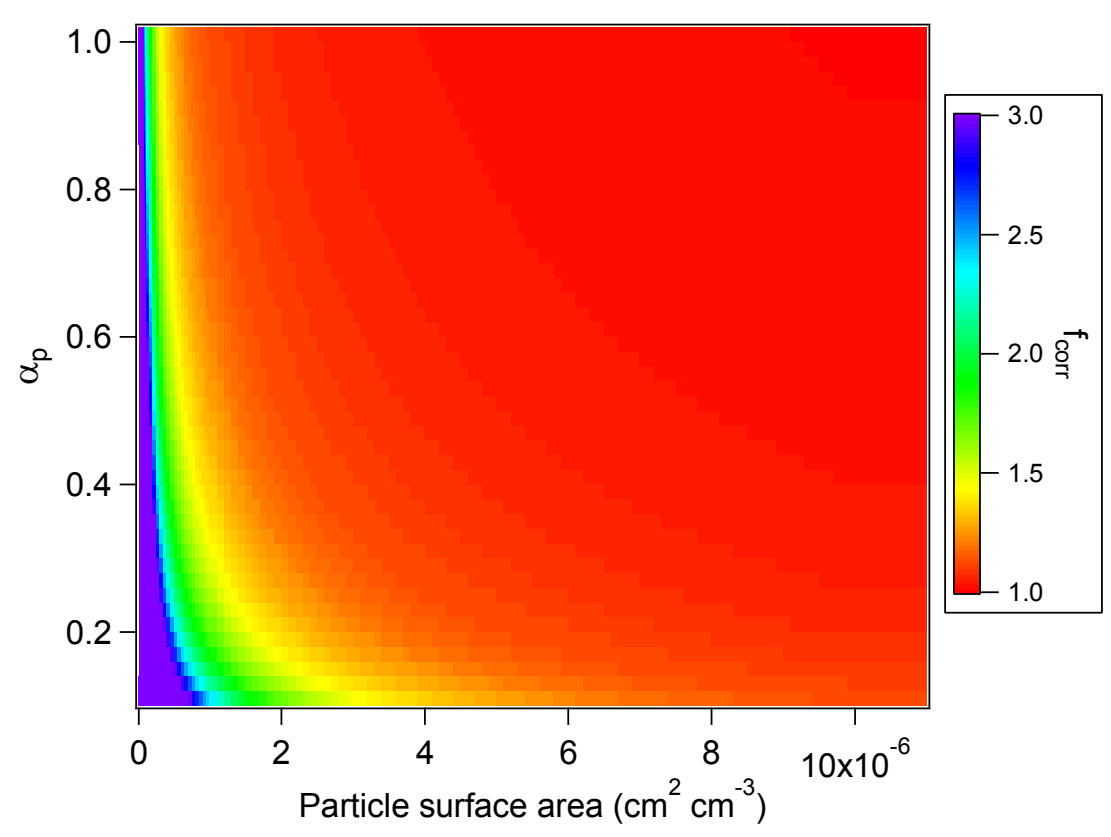

(b)

13 Figure S4. (a) Correction factor $\left(f_{\text {corr }}\right)$ to account for the influence of vapor wall loss on SOA yield. The curves 14 were derived using an average molecular weight of $200 \mathrm{~g} / \mathrm{mol}$ and an accommodation coefficient $\left(\alpha_{\mathrm{p}}\right)$ on particles 15 of 0.1 and 1 , respectively. The lines show the $f_{\text {corr }}$ as a function of aerosol surface area concentration and solid 16 squares show the peak aerosol surface area concentration in each experiment. The experiments corresponding to 17 each points are shown. " $\alpha-p$ " and "L" denote $\alpha$-pinene and limonene, respectively. "L" and " $H$ " denote low and 18 high, respectively. For example, " $\alpha-\mathrm{p}-\mathrm{H} \mathrm{NO}_{\mathrm{x}}-\mathrm{L} \mathrm{SO}_{2}$ " denote the experiment of $\alpha$-pinene oxidation under high $19 \mathrm{NO}_{\mathrm{x}}$ and low $\mathrm{SO}_{2}$. And the two numbers in each label box show the correction factors ( $\left.f_{\text {corr }}\right)$ derived using $\alpha_{\mathrm{p}}$ of $20 \quad 0.1$ and 1 , respectively. (b). Correction factor $\left(f_{\text {corr }}\right)$ as a function of particle surface area and accommodation 21 coefficient of organic vapors. 


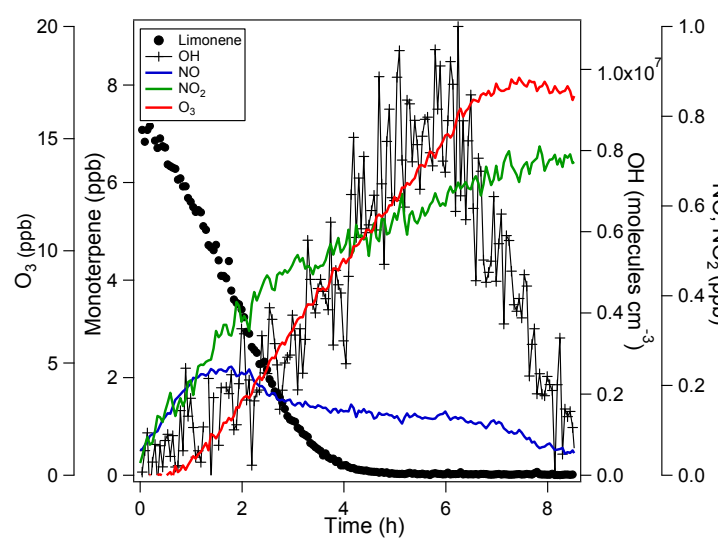

(a)

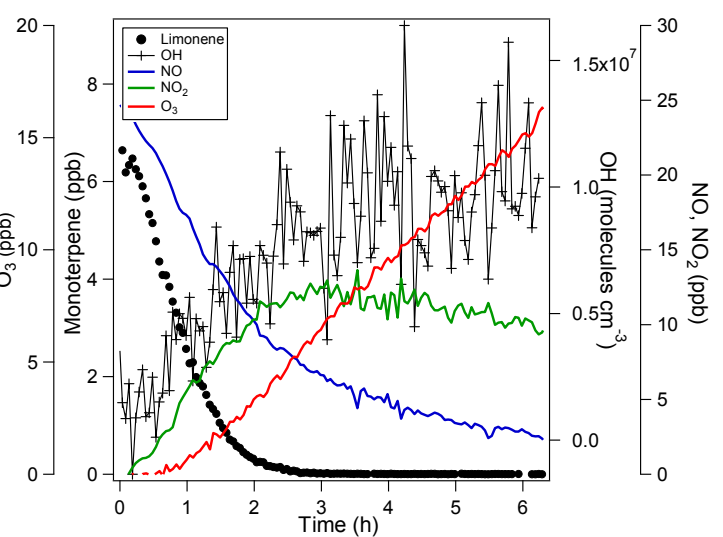

(b)

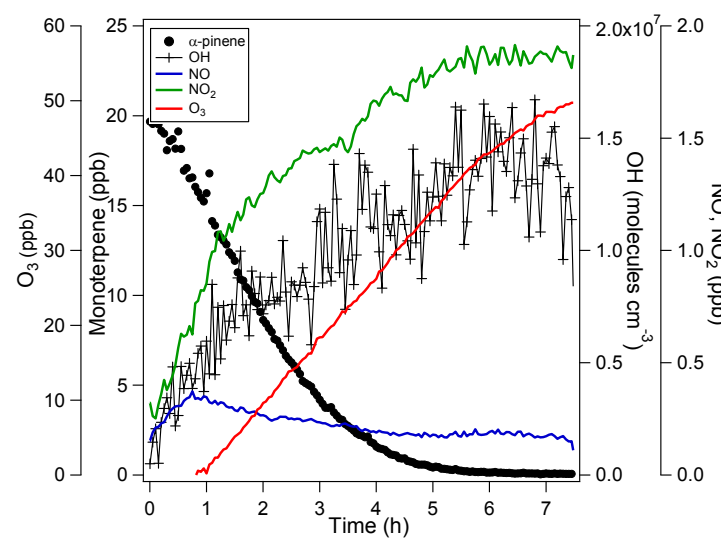

(c)

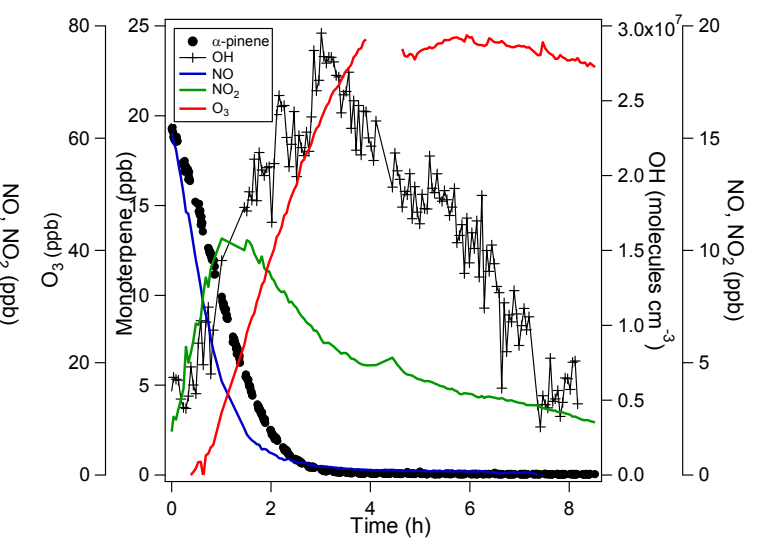

(d)

Figure S5. Time series of $\mathrm{VOC}, \mathrm{OH}, \mathrm{NO}, \mathrm{NO}_{2}$, and $\mathrm{O}_{3}$ concentrations at low $\mathrm{SO}_{2}$ for low $\mathrm{NO}_{\mathrm{x}}(\mathrm{a}, \mathrm{c})$ and high $\mathrm{NO}_{\mathrm{x}}(\mathrm{b}, \mathrm{d}) .(\mathrm{a}, \mathrm{b})$ and $(\mathrm{c}, \mathrm{d})$ are for limonene and $\alpha$-pinene photooxidation, respectively. Similar trends were observed under high $\mathrm{SO}_{2}$. 


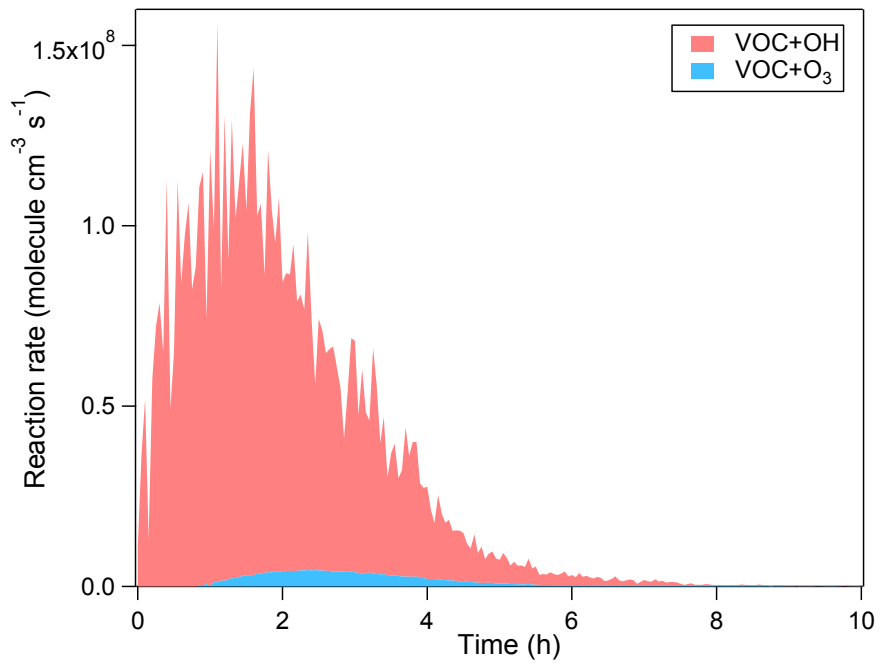

32 Figure S6. Comparison of the reaction rates of monoterpene with $\mathrm{OH}$ and with $\mathrm{O}_{3}$ in a typical experiment of this 33 study. The reaction rate of $\mathrm{VOC}+\mathrm{OH}$ is stacked on that of $\mathrm{VOC}+\mathrm{O}_{3}$. Monoterpene oxidation was dominated by $34 \mathrm{OH}$ oxidation. Here the data in $\alpha$-pinene photooxidation at low $\mathrm{NO}_{\mathrm{x}}$ are shown. The scattering of the reaction rate 35 of monoterpene with $\mathrm{OH}$ is due to the variations in the $\mathrm{OH}$ concentrations and $\mathrm{OH}$ measurement. 


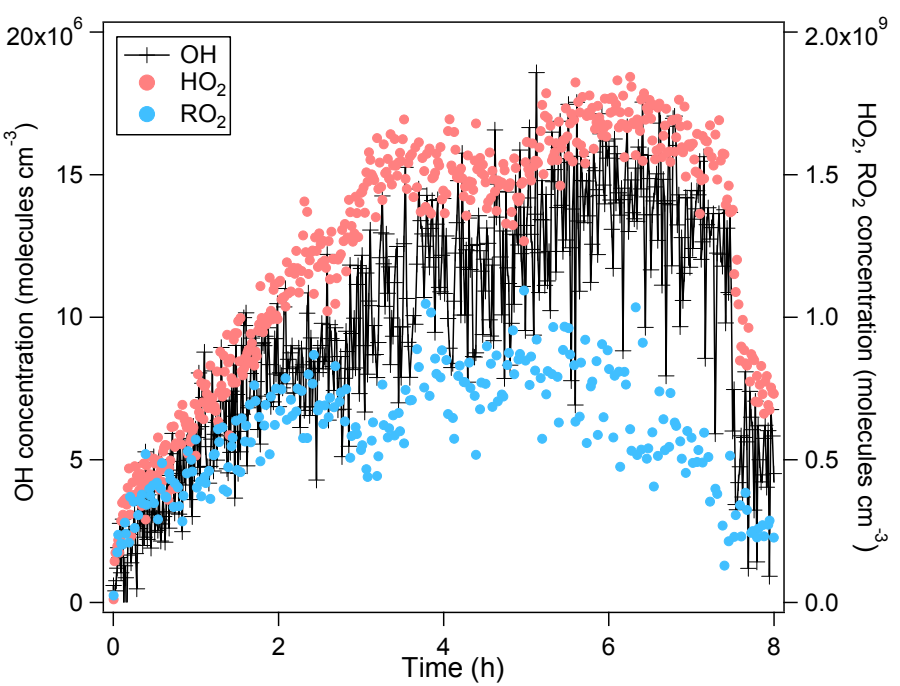

38 Figure $\mathrm{S} 7$. The concentrations of $\mathrm{OH}, \mathrm{HO}_{2}$ and $\mathrm{RO}_{2}$ radicals in a typical experiment of this study. Here the data in $\alpha$-pinene photooxidation at low $\mathrm{NO}_{\mathrm{x}}$ are shown. 
40

41

42

43

44 Figure S8. SOA yield from the photooxidation of $\alpha$-pinene (a) and limonene (b) as a function of organic aerosol

45 concentration $\left(\mathrm{C}_{\mathrm{OA}}\right)$ in different $\mathrm{NO}_{\mathrm{x}}$ and $\mathrm{SO}_{2}$ conditions. Both $\mathrm{SOA}$ yield and organic aerosol concentration were

46 corrected for particle wall loss and dilution.

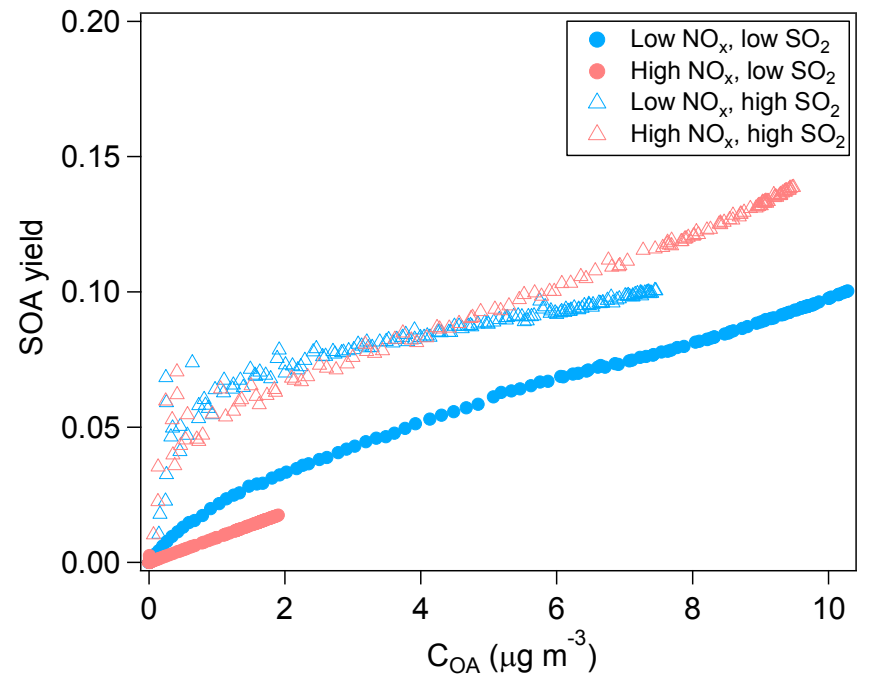

(a)

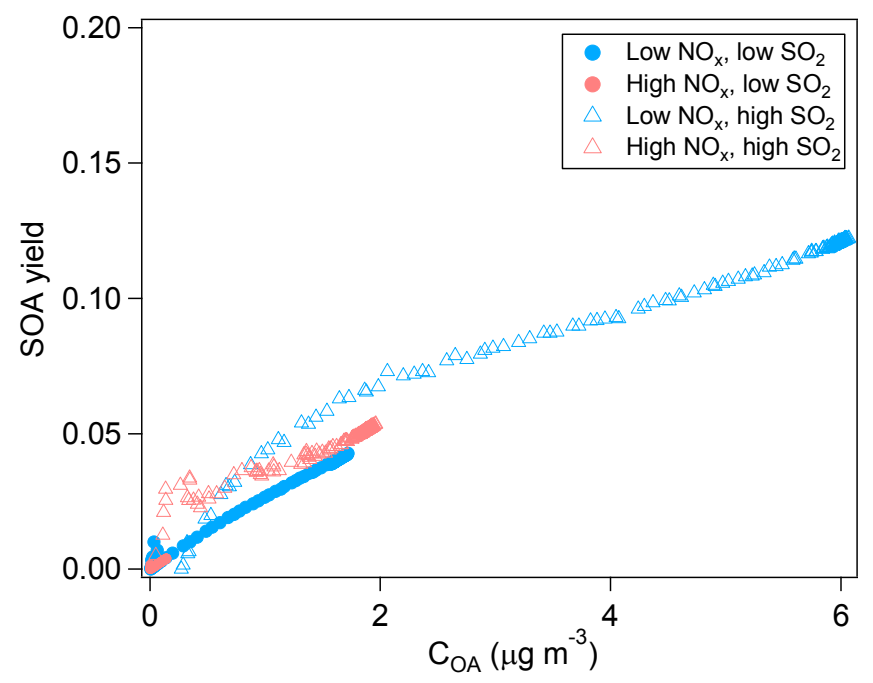

(b) 


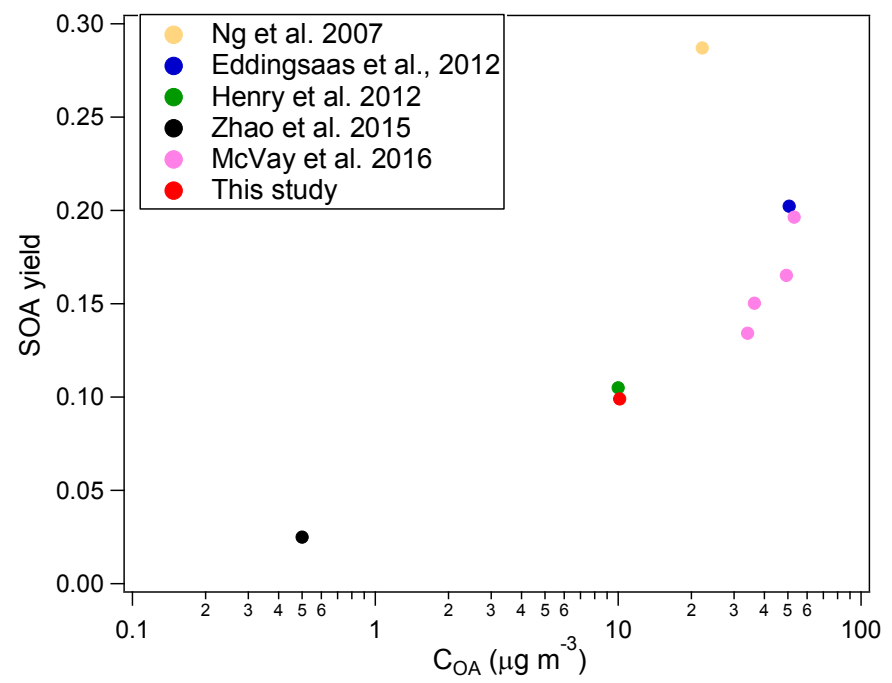

49 Figure S9. Comparison of the SOA yield as a function of organic aerosol concentration from $\alpha$-pinene 50 photooxidation at low $\mathrm{NO}_{\mathrm{x}}$ with literature data. SOA yield and organic aerosol concentration in this study were 51 corrected for particle wall loss and dilution. SOA particle density in all studies was adjusted to $1 \mathrm{~g} \mathrm{~cm}^{-3}$. The data 52 for Henry et al. (2012) was extracted from Figure 2, experiment 1 in their study. The data for McVay et al. (2016) 53 were extracted from Figure 2-4 in their study. The data extracted from figures in the literature may be subject to 54 uncertainties. 


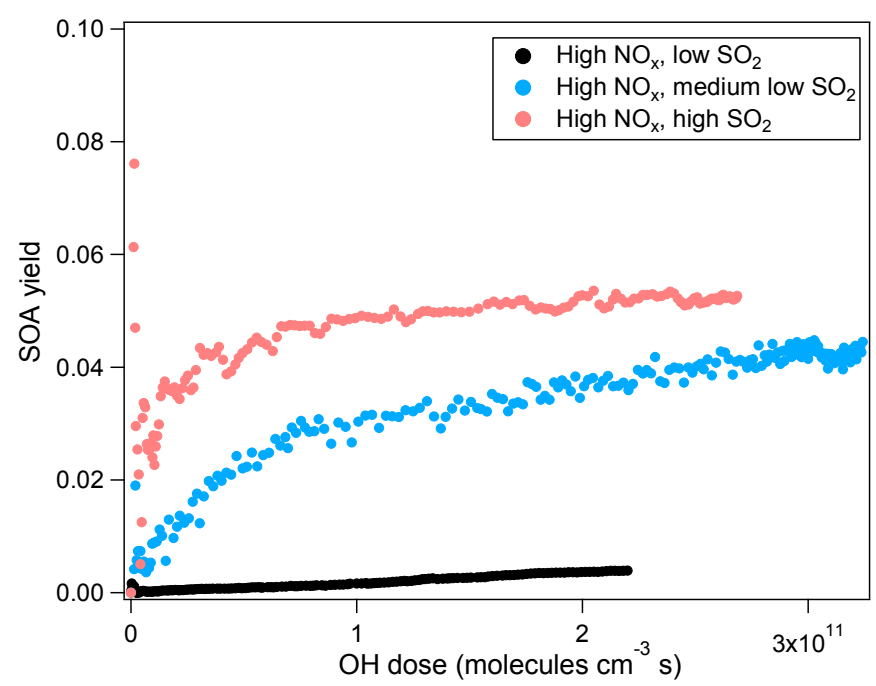

57 Figure $\mathrm{S} 10$. SOA yield at varying $\mathrm{SO}_{2}$ concentrations for SOA from limonene oxidation at high $\mathrm{NO}_{\mathrm{x}}$. The $\mathrm{SO}_{2}$

58 concentrations for low $\mathrm{SO}_{2}$, moderate $\mathrm{SO}_{2}$ and high $\mathrm{SO}_{2}$ are $<0.05 \mathrm{ppb}, 2 \mathrm{ppb}$ and $15 \mathrm{ppb}$, respectively. 


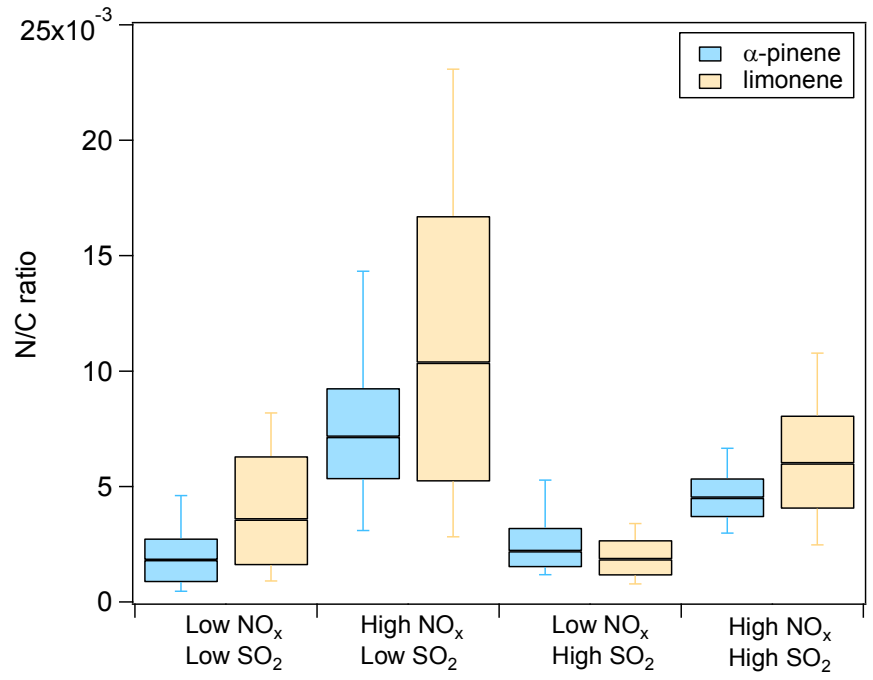

60 Figure S11. The nitrogen to carbon ratio $(\mathrm{N} / \mathrm{C})$ in the SOA formed in different conditions for $\alpha$-pinene and 61 limonene oxidation. The black line, box, and whiskers show the median, $25^{\text {th }}$ and $75^{\text {th }}$ percentile, and $10^{\text {th }}$ and $90^{\text {th }}$ 62 percentile, respectively. 

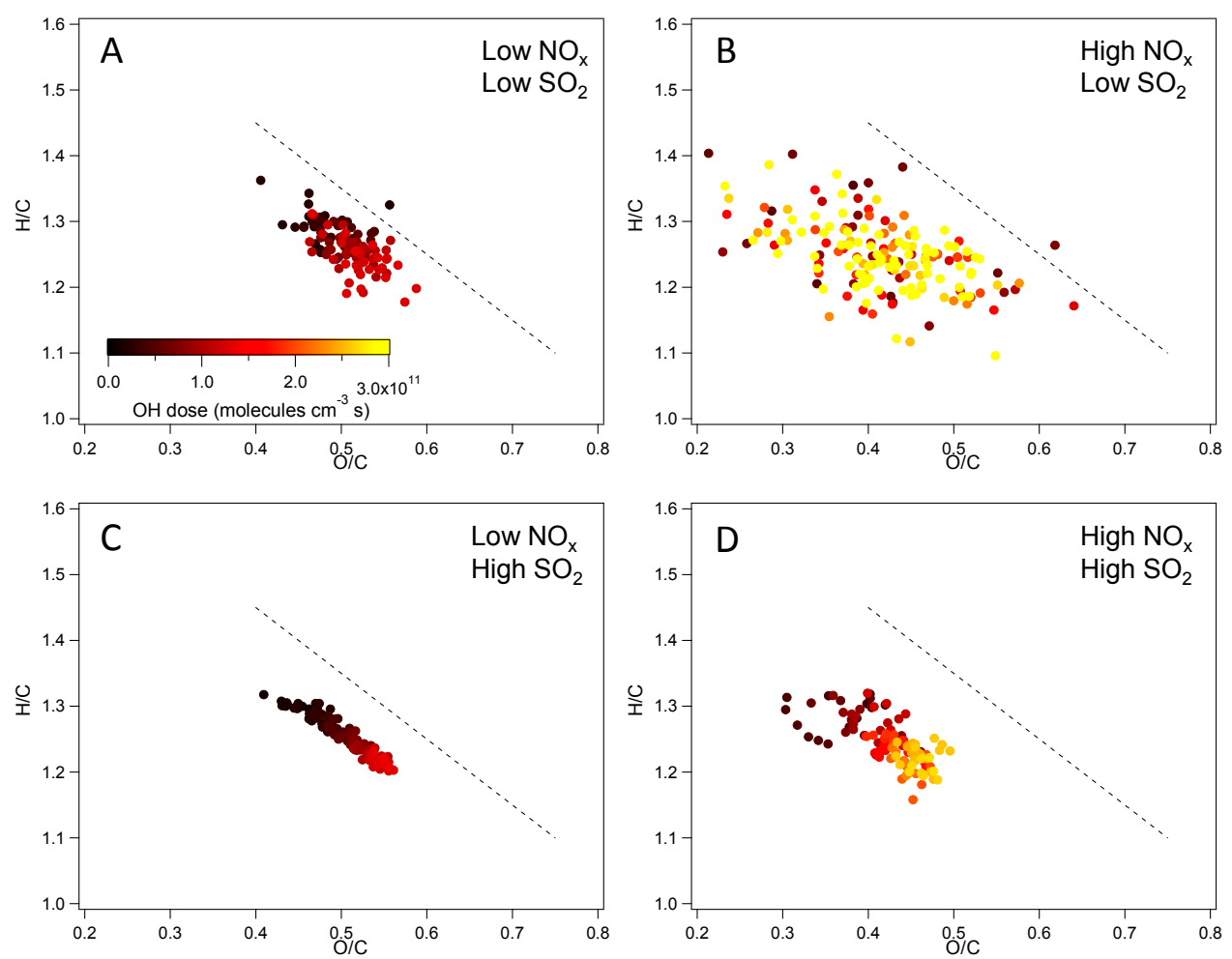

64 Figure $\mathrm{S} 12 . \mathrm{H} / \mathrm{C}$ and $\mathrm{O} / \mathrm{C}$ ratios of $\mathrm{SOA}$ from photooxidation of limonene in different $\mathrm{NO}_{\mathrm{x}}$ and $\mathrm{SO}_{2}$ conditions.

65 A: low $\mathrm{NO}_{\mathrm{x}}$, low $\mathrm{SO}_{2}$, B: high $\mathrm{NO}_{\mathrm{x}}$, low $\mathrm{SO}_{2}, \mathrm{C}$ : low $\mathrm{NO}_{\mathrm{x}}$, high $\mathrm{SO}_{2}$, D: high $\mathrm{NO}_{\mathrm{x}}$, high $\mathrm{SO}_{2}$. Note that in the 66 high $\mathrm{NO}_{x}$, low $\mathrm{SO}_{2}$ condition (panel B), the AMS signal was too low to derive reliable $\mathrm{H} / \mathrm{C}$ and $\mathrm{O} / \mathrm{C}$ due to the 67 low particle mass concentration and small particle size. Therefore, the data from an experiment with high $\mathrm{NO}_{\mathrm{x}}$ 68 (20 ppb NO) and moderate $\mathrm{SO}_{2}(2 \mathrm{ppb})$ is shown instead in panel $\mathrm{B}$. The black dashed line corresponds to the 69 slope of -1. 

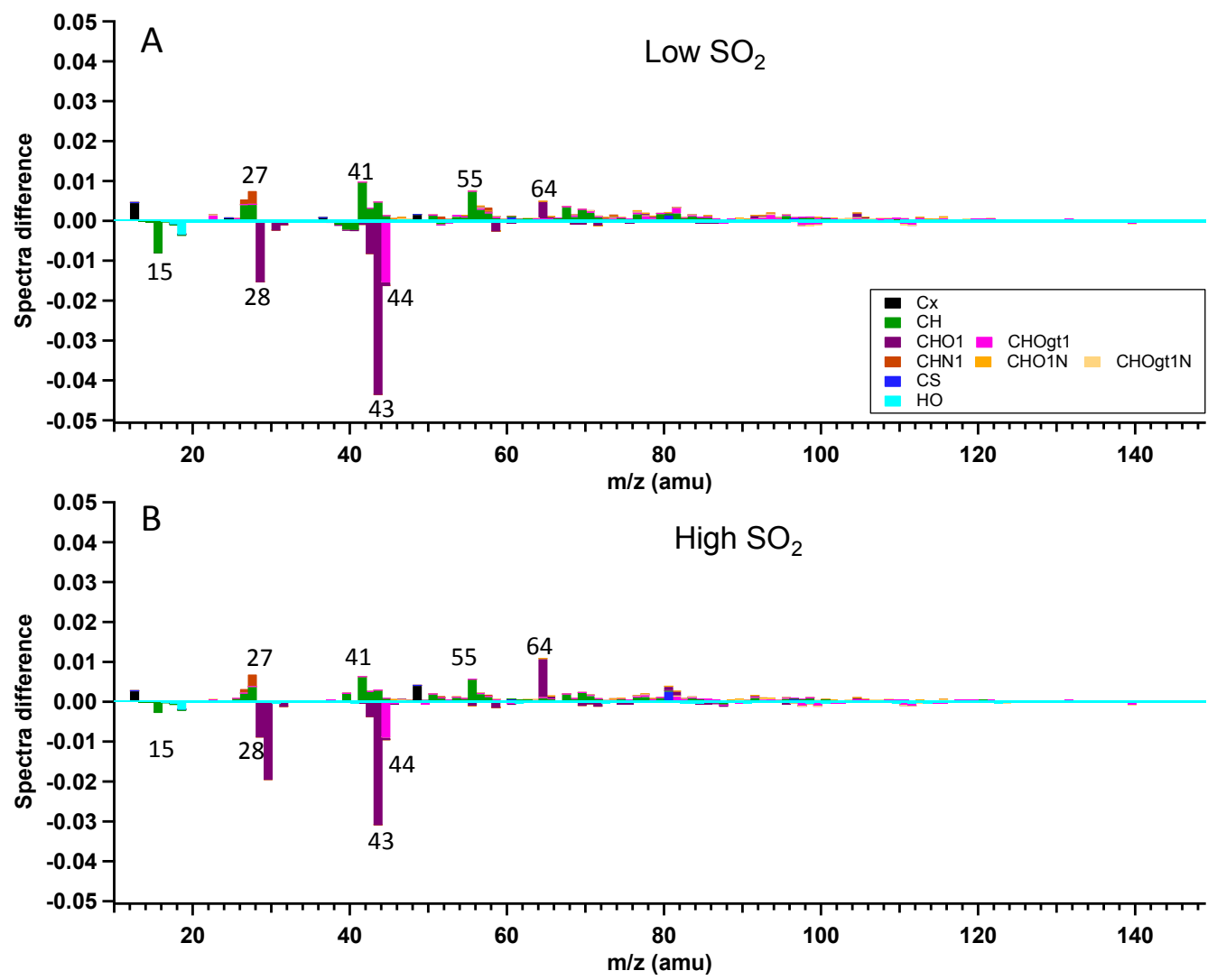

Figure S13. The difference in the mass spectra of organics of the SOA from limonene photooxidation between

73 high $\mathrm{NO}_{\mathrm{x}}$ and low $\mathrm{NO}_{\mathrm{x}}$ conditions (high $\mathrm{NO}_{\mathrm{x}}$-low $\mathrm{NO}_{\mathrm{x}}$ ). SOA was formed at low $\mathrm{SO}_{2}$ (a) and high $\mathrm{SO}_{2}$ (b). The

74 different chemical family of high resolution mass peaks are stacked at each unit mass $\mathrm{m} / \mathrm{z}$ ("gt1" means greater

75 than 1). The mass spectra were normalized to the total organic signals. Note that in the high $\mathrm{NO}_{\mathrm{x}}$, low $\mathrm{SO}_{2}$

76 condition (panel A), the signal of AMS was too low. Therefore, the data in panel A show an experiment with

77 high $\mathrm{NO}_{\mathrm{x}}(20 \mathrm{ppb} \mathrm{NO})$ and moderate $\mathrm{SO}_{2}(2 \mathrm{ppb})$ instead. 
Aiken, A. C., DeCarlo, P. F., and Jimenez, J. L.: Elemental analysis of organic species with electron ionization high-resolution mass spectrometry, Anal. Chem., 79, 8350-8358, 10.1021/ac071150w, 2007. Canagaratna, M. R., Jimenez, J. L., Kroll, J. H., Chen, Q., Kessler, S. H., Massoli, P., Hildebrandt Ruiz, L., Fortner, E., Williams, L. R., Wilson, K. R., Surratt, J. D., Donahue, N. M., Jayne, J. T., and Worsnop, D. R.: Elemental ratio measurements of organic compounds using aerosol mass spectrometry: characterization, improved calibration, and implications, Atmos. Chem. Phys., 15, 253-272, 10.5194/acp-15-253-2015, 2015.

Eddingsaas, N. C., Loza, C. L., Yee, L. D., Chan, M., Schilling, K. A., Chhabra, P. S., Seinfeld, J. H., and Wennberg, P. O.: alpha-pinene photooxidation under controlled chemical conditions - Part 2: SOA yield and composition in low- and high-NOx environments, Atmos. Chem. Phys., 12, 7413-7427, 10.5194/acp-12-7413-2012, 2012.

Han, Y. M., Stroud, C. A., Liggio, J., and Li, S. M.: The effect of particle acidity on secondary organic aerosol formation from alpha-pinene photooxidation under atmospherically relevant conditions, Atmos. Chem. Phys., 16, 13929-13944, 10.5194/acp-16-13929-2016, 2016.

Henry, K. M., Lohaus, T., and Donahue, N. M.: Organic Aerosol Yields from alpha-Pinene Oxidation: Bridging the Gap between First-Generation Yields and Aging Chemistry, Environ. Sci. Technol., 46, 12347-12354, 10.1021/es302060y, 2012.

McVay, R. C., Zhang, X., Aumont, B., Valorso, R., Camredon, M., La, Y. S., Wennberg, P. O., and Seinfeld, J. H.: SOA formation from the photooxidation of alpha-pinene: systematic exploration of the simulation of chamber data, Atmos. Chem. Phys., 16, 2785-2802, 10.5194/acp-16-2785-2016, 2016.

Ng, N. L., Chhabra, P. S., Chan, A. W. H., Surratt, J. D., Kroll, J. H., Kwan, A. J., McCabe, D. C., Wennberg, P. O., Sorooshian, A., Murphy, S. M., Dalleska, N. F., Flagan, R. C., and Seinfeld, J. H.: Effect of $\mathrm{NO}(\mathrm{x})$ level on secondary organic aerosol (SOA) formation from the photooxidation of terpenes, Atmos. Chem. Phys., 7, 5159-5174, 2007.

Presto, A. A., Hartz, K. E. H., and Donahue, N. M.: Secondary organic aerosol production from terpene ozonolysis. 2. Effect of NOx concentration, Environ. Sci. Technol., 39, 7046-7054, 10.1021/es050400s, 2005.

Sarrafzadeh, M., Wildt, J., Pullinen, I., Springer, M., Kleist, E., Tillmann, R., Schmitt, S. H., Wu, C., Mentel, T. F., Zhao, D. F., Hastie, D. R., and Kiendler-Scharr, A.: Impact of NOx and OH on secondary organic aerosol formation from beta-pinene photooxidation, Atmos. Chem. Phys., 16, 11237-11248, 10.5194/acp-16-11237-2016, 2016.

Stirnweis, L., Marcolli, C., Dommen, J., Barmet, P., Frege, C., Platt, S. M., Bruns, E. A., Krapf, M., Slowik, J. G., Wolf, R., Prevot, A. S. H., Baltensperger, U., and El-Haddad, I.: Assessing the influence of NOx concentrations and relative humidity on secondary organic aerosol yields from alpha-pinene photo-oxidation through smog chamber experiments and modelling calculations, Atmos. Chem. Phys., 17, 5035-5061, 10.5194/acp-17-5035-2017, 2017. 